\title{
Endothelin-1 receptors play a minor role in the protection against acute Trypanosoma cruzi infection in mice
}

E. Roffêe ${ }^{1}$, A.L.S. Souza ${ }^{1}$,

P.P. Machado ${ }^{1}$,

L.S. Barcelos ${ }^{1}$,

A.J. Romanha ${ }^{3}$,

F.S. Mariano ${ }^{4}$,

J.S. Silva ${ }^{4}$, C.R. Machado ${ }^{2}$,

H.B. Tanowitz ${ }^{5}$

and M.M. Teixeira ${ }^{1}$

\author{
1Departamento de Bioquímica e Imunologia, '2Departamento de Morfologia, \\ Instituto de Ciências Biológicas, Universidade Federal de Minas Gerais, \\ Belo Horizonte, MG, Brasil \\ ${ }^{3}$ Centro de Pesquisas René Rachou, Fiocruz, Belo Horizonte, MG, Brasil \\ ${ }^{4}$ Departamento de Bioquímica e Imunologia, \\ Faculdade de Medicina de Ribeirão Preto, Universidade de São Paulo, Ribeirão Preto, \\ SP, Brasil \\ ${ }^{5}$ Albert Einstein College of Medicine and Montefiore Medical Center, Bronx, NY, USA
}

\section{Correspondence}

M.M. Teixeira

Departamento de Bioquímica e Imunologia, ICB, UFMG

Avenida Antonio Carlos, 6627

31270-901 Belo Horizonte, MG

Brasil

Fax: +55-31-3499-2651

E-mail: mmtex@icb.ufmg.br

Rersearch supported by CAPES, FAPEMIG, and NIH/FIRCA

(1 R03-TW006857-01A1, USA).

Publication supported by FAPESP.

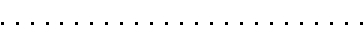

Received July 11, 2006 Accepted January 3, 2007

\section{Abstract}

Chagas' disease, caused by the protozoan Trypanosoma cruzi, is a major cause of cardiovascular disability in countries where it is endemic. Damage to the heart microvasculature has been proposed to be an important factor in the pathogenesis of heart dysfunction. Endothelin-1 (ET-1) is a potent vasoconstrictor and exerts its effects via specific $\mathrm{ET}_{\mathrm{A}}$ and $\mathrm{ET}_{\mathrm{B}}$ receptors. A few studies have suggested a role for ET-1 and its receptors in the pathogenesis of Chagas' disease. We investigated the effects of treatment with bosentan, an $\mathrm{ET}_{\mathrm{A}} / \mathrm{ET}_{\mathrm{B}}$ receptor antagonist, on the course of $T$. cruzi infection (Y strain) in C57Bl/6 mice. Treatment with bosentan $\left(100 \mathrm{mg} \mathrm{kg}^{-1} \mathrm{day}^{-1}\right)$ was given per os starting day 0 after infection until sacrifice. Bosentan significantly increased myocardial inflammation, with no effects on parasitemia. Although the total number of nests was similar, a lower number of intact amastigote nests was found in the heart of bosentan-treated animals. Bosentan failed to affect the infection-associated increase in the cardiac levels of the cytokines IFN- $\gamma$ and TNF- $\alpha$ and the chemokines CCL2/MCP-1, CCL3/MIP-1 $\alpha$ and CCL5/RANTES. In vitro, pre-incubation with ET-1 $(0.1 \mu \mathrm{M}) 4 \mathrm{~h}$ before infection enhanced the uptake of the parasites by peritoneal macrophages, and this effect was abrogated when macrophages were pre-treated with bosentan $(1 \mu \mathrm{M})$ 15 min before incubation with ET-1. However, ET-1 did not alter killing of intracellular parasites after $48 \mathrm{~h}$ of in vitro infection. Our data suggest that bosentan-treated mice have a delay in controlling parasitism which is compensated for exacerbated inflammation. Infection is eventually controlled in these animals and lethality is unchanged, demonstrating that ET-1 plays a minor role in the protection against acute murine $T$. cruzi infection.
Key words

- Trypanosoma cruzi

- Endothelin

- Myocarditis

- Chemokines 


\section{Introduction}

Chagas' disease is caused by the protozoan parasite Trypanosoma cruzi and infects over 15 million people in Latin America. Chagas' heart disease is a major cause of cardiovascular disability in countries where it is endemic. The main pathological finding in the heart of infected patients and susceptible animal models is a chronic progressive and fibrosing myocarditis, with a structural disarrangement that causes the malfunctioning of the organ and results in heart failure, ventricular arrhythmias and cardiac hypertrophy (1). Damage to the microvasculature of the heart is suggested to be an important factor in the pathogenesis of heart dysfunction.

Endothelin-1 (ET-1) was first characterized as a protease-sensitive vasoconstrictor substance produced by endothelial cells in culture $(2,3)$ and isolated from the culture medium of porcine aortic cells (4). ET-1 is considered to be the most potent vasoconstrictor substance known and exerts its effects via binding to specific $\mathrm{ET}_{\mathrm{A}}$ and $\mathrm{ET}_{\mathrm{B}}$ receptors. Whereas the major effects of $\mathrm{ET}_{\mathrm{A}}$ receptors seem to be associated with vasoconstriction and cell proliferation, $\mathrm{ET}_{\mathrm{B}}$ controls ET-1 levels and endothelin-converting enzyme-1 activity (5).

Increased circulating levels of ET-1 are found in animals and humans with hypertension, heart failure, atherosclerosis, and a variety of cardiovascular pathologies, including Chagas' disease (6). An increase in physiologically active ET-1 production by human endothelial cells infected with $T$. cruzi was first observed in 1995 (7). Moreover, in T. cruzi-infected animals, ET-1 was observed in cardiac myocytes and endothelium and in association with an intense vasculitis, providing a mechanism for infection-associated myocardial dysfunction $(8,9)$. Studies using inhibitors of ET-1 synthesis support a role for ET-1 in the pathogenesis of heart dysfunction. In T. cruzi-infected mice, treat- ment with phosphoramidon, an endothelinconverting enzyme and neutral endopeptidase inhibitor, and verapamil, a first generation L-type calcium channel antagonist, reduced or abrogated mortality and attenuated cardiac pathology and dysfunction parameters (10-13). Similarly, treatment with BSF461314, an $\mathrm{ET}_{\mathrm{A}}$ receptor antagonist, was able to prevent changes in coronary flow in T. cruzi-infected rats $(14,15)$. In the latter studies, $\mathrm{ET}_{\mathrm{A}}$ receptor antagonist treatment was associated with enhanced parasitemia, inflammation and parasitism in myocardium and diaphragm. An increase of myocardial parasite load and inflammation was observed also in rats treated with the $\mathrm{ET}_{\mathrm{A} / \mathrm{B}}$ receptor antagonist bosentan (16). These findings suggest that ET-1 is part of a cascade of events leading to a protective immune response against acute $T$. cruzi infection in rats (14-16). However, the role of ET-1 in the ability of the host to deal with infection has not been determined in any other species. Therefore, the aim of the present study was to determine whether ET-1 and its receptors play a protective role during acute $T$. cruzi infection in mice. To this end, bosentantreated mice were infected with the $\mathrm{Y}$ strain of $T$. cruzi and infection and inflammatory indices were evaluated.

\section{Material and Methods}

\section{Animals and infection}

Seven- to 10-week-old male C57B1/6 mice were obtained from CEBIO, UFMG (Belo Horizonte, MG, Brazil) and maintained in the animal facilities of the Laboratório de Imunofarmacologia, with filtered water and food ad libitum. Animals were infected intraperitoneally with 5000 blood forms of the $\mathrm{Y}$ strain of T. cruzi. The strain is maintained by serial passages in $\mathrm{C} 57 \mathrm{Bl} / 6$ mice in the Laboratório de Parasitologia Celular e Molecular, CPqRR, Fiocruz (Belo Horizonte, MG, Brazil). Groups of 5-7 animals were 
sacrificed 10, 15, and 20 days post-infection, and the myocardium was collected.

All animal procedures were approved by the local Animal Ethics Committee (CETEA, UFMG). Parasitemia was estimated according to Brener's method (16) every 2 or 3 days in $5 \mu \mathrm{L}$ of peripheral blood sampled from the tail vein of $T$. cruzi-infected mice.

\section{Treatment with bosentan}

Bosentan (N-[6-(2-hydroxyethoxy)-5-(2methoxyphenoxy)-2-pyrimidin-2-yl-pyrimidin-4-yl]-4-tert-butyl-benzenesulfonamidean) was kindly donated by Actelion (Allschwil, Switzerland). The dose of bosentan used in the present experiments $\left(100 \mathrm{mg} \mathrm{kg}^{-1}\right.$ day $\left.^{-1}\right)$ was recommended by the manufacturer (Actelion) and found to be effective for chronic $\mathrm{ET}_{\mathrm{A}}$ and $\mathrm{ET}_{\mathrm{B}}$ blockade in other studies (17). The drug was diluted in a suspension containing $5 \%$ gum arabic and administered per os every $24 \mathrm{~h}$. Mice were divided into three groups: bosentan, T. cruzi-infected and bosentan-treated mice; vehicle, T. cruziinfected and PBS-treated mice, and a noninfected group in the presence and absence of the drug. There was no difference between data from non-infected mice treated or not with bosentan, therefore these data were pooled as a non-infected group to facilitate data presentation.

\section{Histopathological studies}

The heart of animals from the three groups was collected on different days after infection and sectioned transversely into two parts. One part was immediately fixed in $4 \%$ buffered paraformaldehyde, processed for paraffin embedding, cut into $7-\mu \mathrm{m}$ sections with a microtome and stained with hematoxylin and eosin. Cardiac parasitism and inflammation of hearts from 5-7 animals per group were analyzed with a Zeiss microscope (Öberkohen, Germany) with an integrating eyepiece with 100 hits at a final magnifica- tion of 320X. A total of 4000 hits were evaluated in each section of cardiac tissue. The inflammation index represents the percentage of hits covered by inflammatory cells. The numbers of total, intact and broken amastigote nests were counted in the whole sections and the results are reported as the mean of 3 sections analyzed per animal.

\section{Cytokine detection}

The other part of the heart was processed in a solution containing protease inhibitors and centrifuged at $10,000 \mathrm{~g}$ for $10 \mathrm{~min}$ at $4^{\circ} \mathrm{C}$, as previously described (18). The supernatant was used to detect cytokines by ELISA. ELISA reactions for the detection of IFN- $\gamma$, TNF- $\alpha$, IL-10, CCL2/MCP-1, CCL3/ MIP-1 $\alpha$, and CCL5/RANTES (Duoset, R\&D Systems, Minneapolis, MN, USA) were performed according to manufacturer instructions in 96-well ELISA plates (Nunc Maxisorp, Rochester, NY, USA).

\section{Trypanosoma cruzi uptake and killing by peritoneal macrophages}

In vitro experiments were performed as previously described (19), with some modifications. Briefly, inflammatory macrophages were harvested from the peritoneal cavity of $\mathrm{C} 57 \mathrm{Bl} / 6$ mice 3 days after the injection of $1.5 \mathrm{~mL} \mathrm{3 \% (w/v)} \mathrm{sodium}$ thioglycolate (Sigma, St. Louis, MO, USA). Cells $\left(2 \times 10^{5} / \mathrm{mL}\right)$ were plated onto Labtech chamber slides (Nunclon, Naperville, IL, USA) and incubated overnight at $37^{\circ} \mathrm{C}$. Nonadherent cells were removed by washing with RPMI-1640 medium (Sigma) and adherent cells were treated with ET-1 $(0.1 \mu \mathrm{M})$ for $4 \mathrm{~h}$. In some wells, cells were pre-treated with $1 \mu \mathrm{M}$ bosentan for $15 \mathrm{~min}$ before incubation with ET-1. After $4 \mathrm{~h}$, macrophages were infected with blood trypomastigotes at a parasite-to-cell ratio of 2:1 for $3 \mathrm{~h}$. After incubation with $T$. cruzi, extracellular para- 
sites were removed by washing with RPMI1640 (Sigma) and infected macrophages were incubated at $37^{\circ} \mathrm{C}$ in $5 \% \mathrm{CO}_{2}$ for an additional $2 \mathrm{~h}$ to measure uptake, and for $48 \mathrm{~h}$, to measure killing. The macrophages were fixed with cold methanol and stained with Giemsa solution $(1: 20)$ in order to determine the number of intracellular amastigotes. A total of 200-400 macrophages were analyzed on each slide, and all experiments were carried out in duplicate.

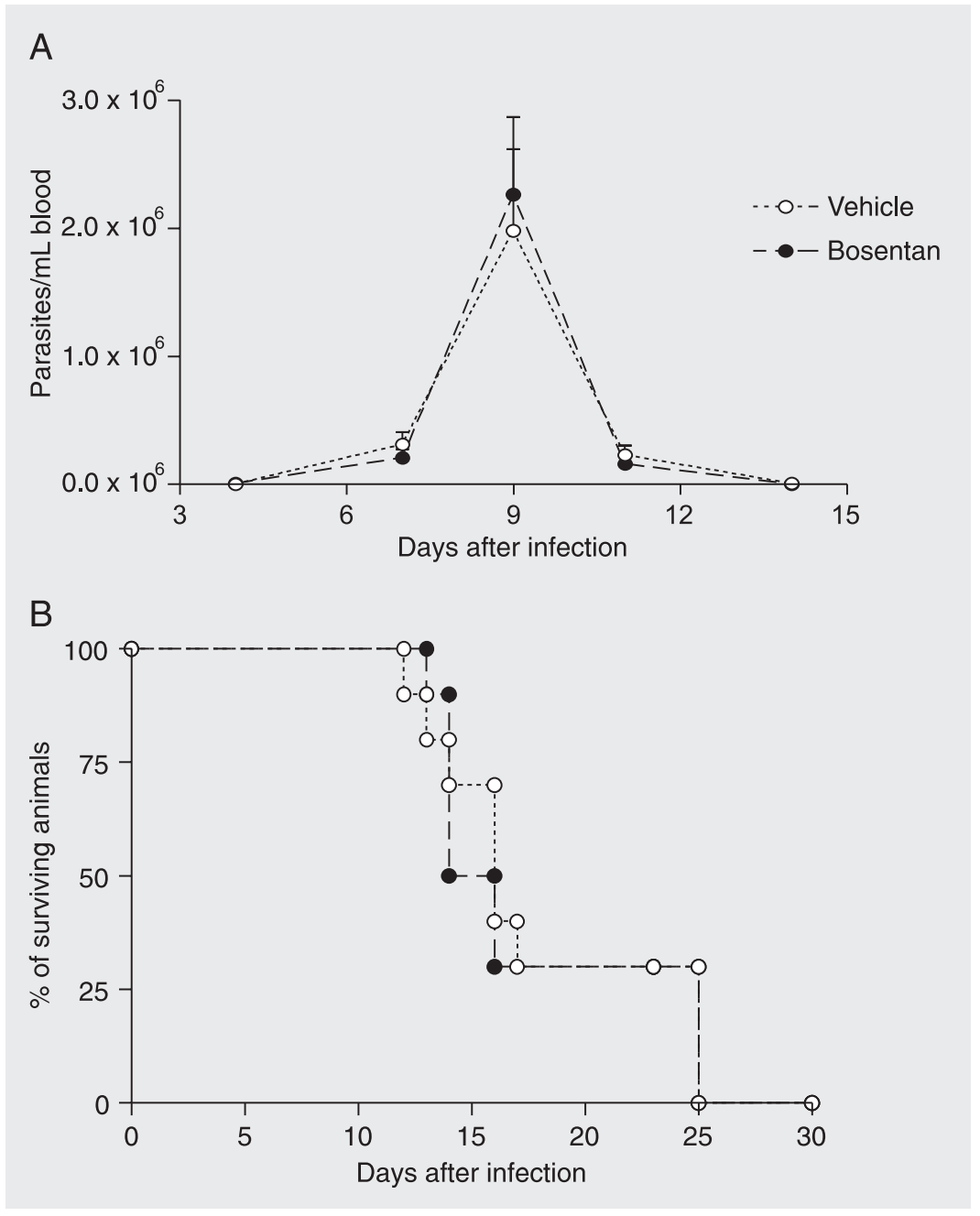

Figure 1. Effect of treatment per os with bosentan on parasitemia (A) and survival (B) curves of Trypanosoma cruzi-infected mice. Vehicle or bosentan (100 mg kg-1 day-1) was administered daily to mice. Parasitemia was assessed every 2 or 3 days and survival was evaluated daily. There were 10 animals in each group and there was no difference between groups. Results are representative of two experiments.

\section{Statistical analysis}

Data are reported as means \pm SEM. Differences between groups were compared by the Student $t$-test (two sets of data) or by one-way ANOVA (three or more sets of data), followed by the post hoc StudentNewman-Keuls test. Differences were considered significant at $\mathrm{P}<0.05$.

\section{Results}

\section{Parasitemia and lethality curves}

The parasitemia of infected mice peaked 9 days after infection. Thereafter, there was a rapid drop in parasitemia and parasite levels were very low or undetectable at 12 days after infection. The parasitemia of bosentantreated mice was similar to that of vehicletreated mice (Figure 1A). Lethality associated with infection was about $75 \%$ between 10 and 18 days after infection. Percent lethality was not significantly changed by treatment with bosentan (Figure 1B).

\section{Myocardial histopathology}

In infected mice, there was an intense and progressive inflammation which peaked on day 15 and was still elevated at day 20 (data not shown). Inflammatory infiltrates were composed mainly of mononuclear cells. The infiltrates were more disperse at day 15 (Figure 2A,D) and more focal at day 20 after infection, at a time when inflammation was mainly associated with broken amastigote nests (data not shown). The peak of myocardial parasitism also occurred 15 days postinfection (Figure 3B,D).

In bosentan-treated mice, there was a significant increase in the intensity of myocarditis both at 10 and 15 days after infection (Figure 2). There did not appear to be any major change in the composition or distribution of the inflammatory infiltrates. The number of amastigote nests in the myocardium 
was similar in bosentan- and vehicle-treated animals (Figure 3A). However, there was a lower number of intact nests in bosentanthan vehicle-treated mice. In addition, the number of broken nests (i.e., nests that were partially disrupted and associated with an intense inflammatory reaction) was increased in bosentan-treated mice (Figure 3A-E).

\section{Levels of cytokines in the heart}

There was a significant increase in the levels of IFN- $\gamma$, TNF- $\alpha$, IL-10, CCL2/MCP1, CCL3/MIP-1 $\alpha$, and CCL5/RANTES at 10 and 15 days in the hearts of $T$. cruziinfected mice when compared with the levels in hearts of uninfected animals. Treatment with bosentan had no significant effect on the cardiac concentrations of IFN- $\gamma$, TNF$\alpha, \mathrm{CCL} 2 / \mathrm{MCP}-1, \mathrm{CCL} 3 / \mathrm{MIP}-1 \alpha$ and CCL5/ RANTES (data not shown). There was only a minor, albeit significant, decrease of IL-10 production on day 15 (vehicle-treated, mean \pm SEM, $3937 \pm 198$ pg/100 mg tissue; bosentan-treated, $3202 \pm 245 \mathrm{pg} / 100 \mathrm{mg}$ tissue, $\mathrm{N}=5, \mathrm{P}<0.05$ ), but not on day 10 (vehicle-treated, $6219 \pm 389$ pg/100 mg tissue; bosentan-treated, $5852 \pm 470$ pg/100 $\mathrm{mg}$ tissue, $\mathrm{N}=5, \mathrm{P}>0.05)$, in bosentantreated infected mice.

\section{In vitro Trypanosoma cruzi uptake and killing}

Treatment of macrophages with ET-1 induced a concentration-dependent increase of parasite uptake (data not shown). Pretreatment with bosentan $(1 \mu \mathrm{M})$ completely inhibited the enhancement of uptake induced by ET-1 (0.1 $\mu \mathrm{M}$; Figure 4A).

We have shown that activation of macrophages with mediators such as chemokines, leukotriene $\mathrm{B}_{4}$ and platelet-activating factor induces an early uptake of parasites that is followed by a significant enhancement of killing at $48 \mathrm{~h}$ (19-21). Akin to the abovementioned mediators, ET-1 is an agonist capable of activating 7-transmembrane-span-
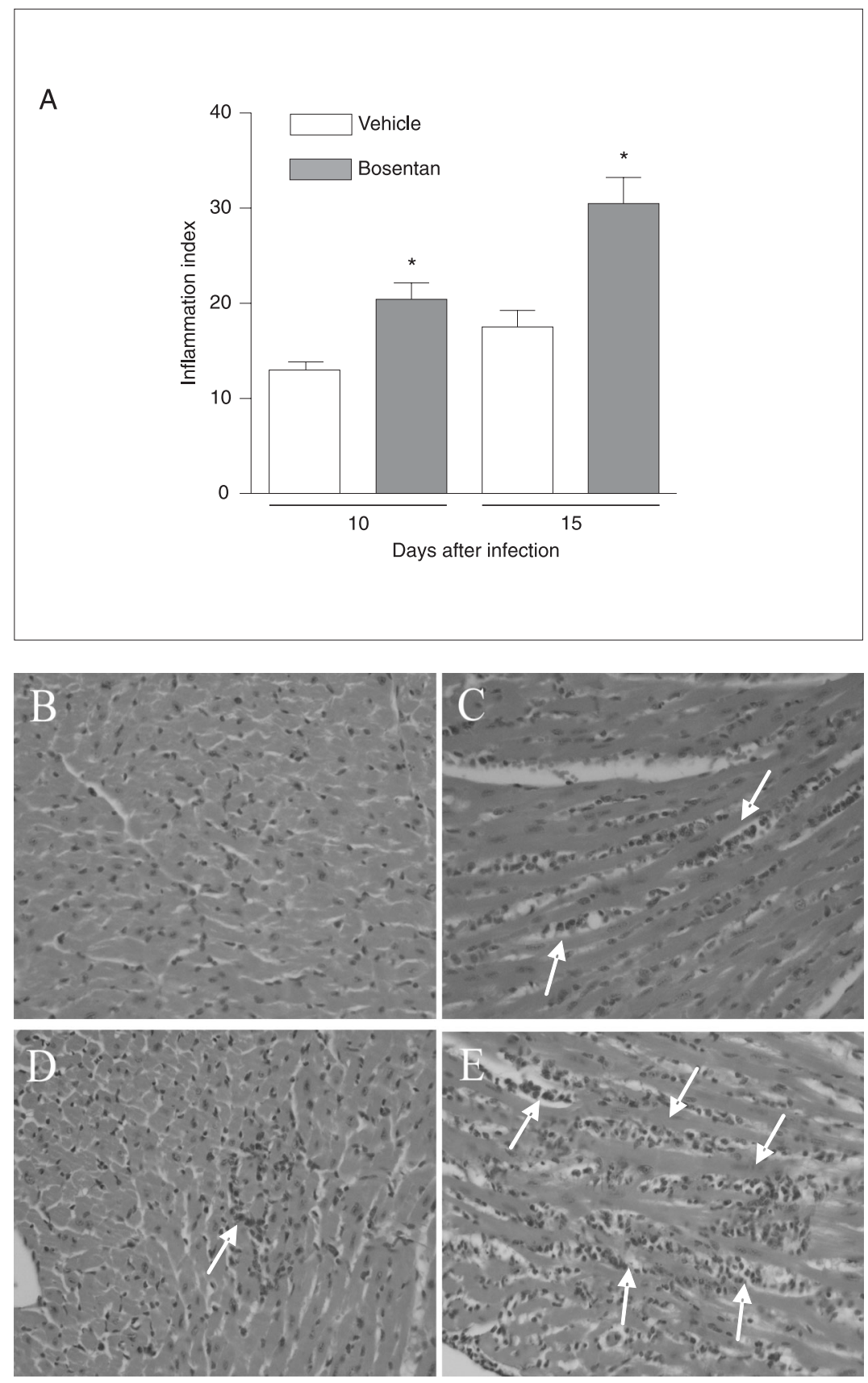

Figure 2. Effect of oral treatment with bosentan on the inflammation in the myocardium of Trypanosoma cruzi-infected mice. The inflammation index was assessed at days 10 and 15 after infection in vehicle- or bosentan (100 mg kg-1 day-1)-treated mice (A). Inflammation was quantified in H\&E-stained sections using an eyepiece containing 100 points/microscopic field at a final magnification of 320X. Forty microscopic fields were analyzed per section, for a total of 4000 points. Results are the means \pm SEM for 5-7 animals in each group and are representative of two experiments. ${ }^{*} \mathrm{P}<0.01$ when comparing bosentantreated vs vehicle-treated animals (Student $t$-test). The pictures show representative histological sections (400X) of vehicle- and bosentan-treated animals on days $10(B, C)$ and 15 $(D, E)$ after infection. The arrows show inflammatory infiltrates in the cardiac tissue. See a detailed description of the histology in the text. 
ning receptors. However, ET-1 was not able to enhance the killing of $T$. cruzi by macrophages (Figure 4B). Moreover, the compound was unable to enhance the killing mediated by a suboptimal concentration of IFN- $\gamma(1 \mathrm{U} / \mathrm{mL})$. For comparison, treatment with IFN- $\gamma(100 \mathrm{U} / \mathrm{mL})$ greatly enhanced the killing of $T$. cruzi by peritoneal macrophages
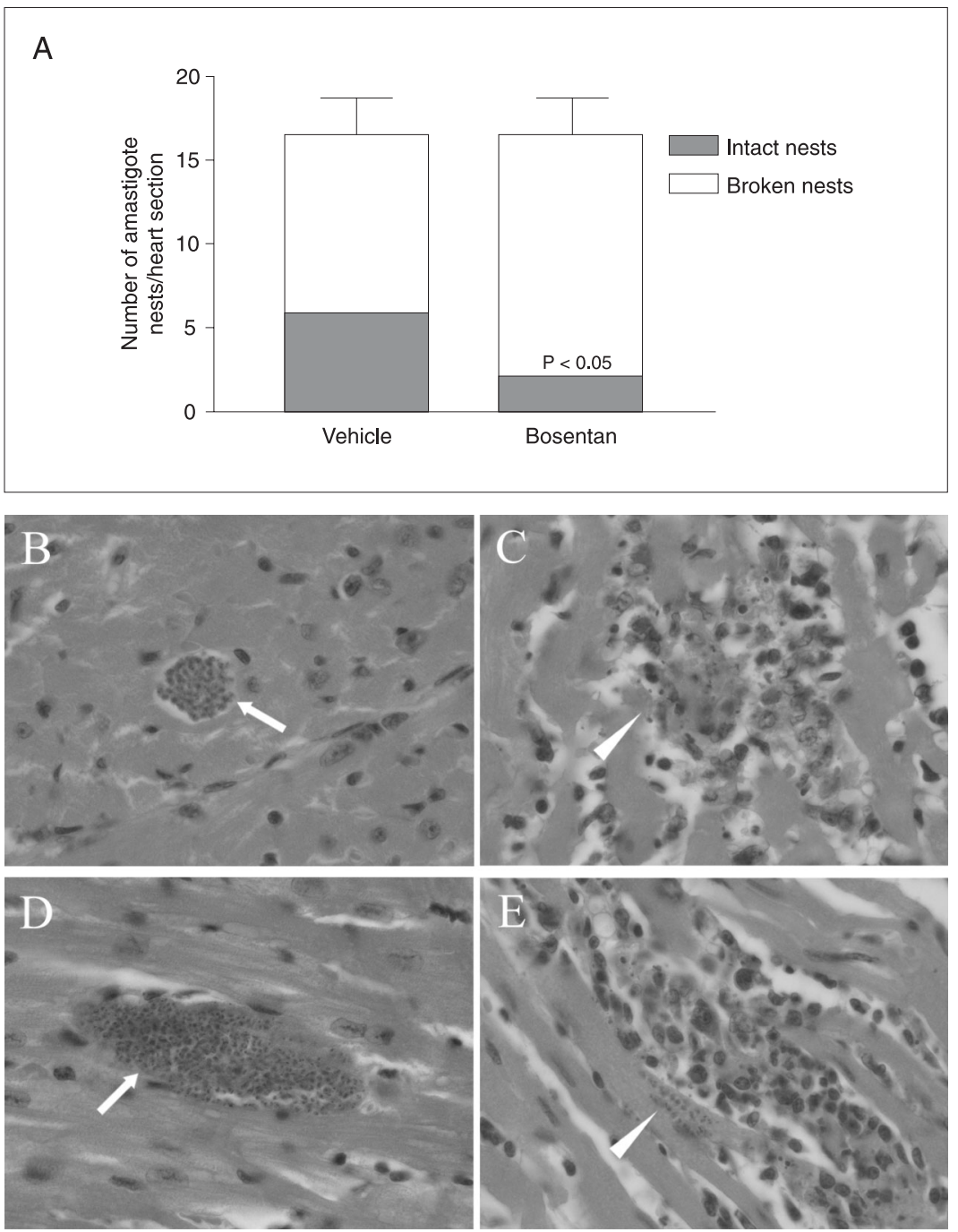

Figure 3. Effect of oral treatment with bosentan on the number of intact and broken parasite nests in the myocardium of Trypanosoma cruzi-infected mice. The number of intact and broken amastigote nests was quantified in the heart sections of $T$. cruzi-infected animals treated with vehicle or bosentan $\left(100 \mathrm{mg} \mathrm{kg}^{-1}\right.$ day $\left.^{-1}\right)$. Data are reported as the mean \pm SEM of 3 H\&E-stained microscopic sections per animal, and 5 to 10 animals were analyzed in each group. The experiment was performed twice. $\mathrm{P}<0.05$ when the number of intact nests in vehicle-treated animals was compared to that of bosentan-treated animals (Student $t$ test). The pictures (1000X) show examples of intact (arrow) and broken (arrowhead) amastigote nests in heart sections of vehicle- $(B, D)$ or bosentan-treated mice $(C, E)$ at day 15 after infection.
(Figure 4B). In vitro, treatment of non-infected cells with bosentan did not induce any detectable change in cell shape or viability after 2 or $48 \mathrm{~h}$ of incubation (data not shown).

\section{Discussion}

In the present study, we investigated whether treatment with an $\mathrm{ET}_{\mathrm{A} / \mathrm{B}}$ receptor antagonist, bosentan, modified the ability of mice to deal with an acute T. cruzi infection. Previous studies have emphasized the potential role of endothelin- 1 and its receptors in mediating structural alterations occurring during chronic infection, including remodeling and hypertrophy (22). Increased ET-1 levels have also been correlated with myocardial dysfunction $(22,23)$. Although vascular reactions caused by the release of ET-1 are well documented (23), less is known about the effects of ET-1 on host defense mechanisms. Previous studies investigated the role of ET- 1 by using the $\mathrm{ET}_{\mathrm{A}}$ antagonist $\mathrm{BSF} 461314$ or the $\mathrm{ET}_{\mathrm{A} / \mathrm{B}}$ receptor antagonist bosentan in rats and revealed exacerbation of parasitemia, myocardial inflammation and parasite loading during the acute phase, suggesting a possible protective role of ET-1 in the infection $(14,15,17)$. We tested the possibility that ET-1 and its receptors would also play a role in controlling parasite replication in mice and investigated mechanisms underlying any possible effects.

Previous studies have shown that ET-1 may mediate or facilitate the production of pro-inflammatory mediators, including CCL2/MCP-1, CCL3/MIP-1 $\alpha$, CCL5/ RANTES, and TNF- $\alpha$ (24-26), in inflammatory conditions such as atherosclerosis (24), LPS-induced pleurisy (25) and glomerulonephritis (26). Thus, $\mathrm{ET}_{\mathrm{A}}$ and $\mathrm{ET}_{\mathrm{B}}$ antagonists behave as anti-inflammatory drugs in the preceding models. In our experiments, treatment with bosentan caused exacerbation of acute myocarditis. In the rat model, treatment with antagonists of ET-1 receptors revealed increased parasitemia and myocardial parasite load and inflammation, sug- 
gesting that these receptors in fact play a role in the defense against $T$. cruzi $(14,15,17)$. However, we also used BSF461314, an $\mathrm{ET}_{\mathrm{A}}$ receptor antagonist, in T. cruzi-infected mice and did not find changes in parasitemia or parasitism (Roffê E, Souza ALS, Machado PP, Barcelos LS, Romanha AJ, Mariano FS, Silva JS, Machado CR, Tanowitz HB, Teixeira MM, unpublished data). The latter observation supports the view that blockade of ET-1 receptors plays only a minor role in T. cruzi infection in the murine model. Similarly to Rachid et al. (17), we detected increased myocardial inflammation, but this was not related to increased parasite levels in blood or myocardium. In the present study, we also failed to detect any changes in chemokine or IFN- $\gamma$ production in the heart after bosentan treatment. Bosentan treatment slightly reduced the levels of IL-10 in the heart in both studies and the fall in IL-10 correlated with the enhanced cardiac inflammatory response. It is not known whether the small fall in IL-10 levels is sufficient to explain the more intense myocarditis observed in bosentan-treated animals.

There was no increase in heart parasitism in bosentan-treated animals in the present study. However, bosentan-treated mice did show a greater ratio of broken/intact nests than vehicle-treated animals, as well as intense inflammation surrounding broken nests. It is possible that the enhanced inflammation observed in animals treated with bosentan was secondary to these broken nests and to the enhanced availability of parasite antigens and parasite-derived molecules. Moreover, it is possible that the enhanced inflammatory response in the presence of similar quantities of pro-inflammatory cytokines may adequately control the infection and prevent any harmful effects of bosentan on the system. Whatever the explanation, it is clear that there was an enhanced inflammatory response in the heart that was capable of controlling parasite replication adequately and without any increase in mortality rates.
In previous studies with rats, treatment with ET-1 receptor antagonists was accompanied by increased parasitemia and myocardial parasite load, suggesting that ET receptors may play a role in the defense against T. cruzi $(14,15,17)$. In addition, bosentantreated rats had reduced serum NOx levels that could account for the higher parasite loads in myocardium and blood (17). ET-1 has been reported to enhance the activation of leukocytes and endothelial cells in a few studies. For example, ET-1 may activate neutrophils to release increased quantities of granule contents (27). ET-1 has been also shown to stimulate endothelial cells, mast cells and macrophages (28-31). Since treatment of bosentan was associated with increased numbers of broken nests and lower numbers of intact nests, we may suggest that ET-1 played a direct role in the ability of host macrophages to deal with the infection.
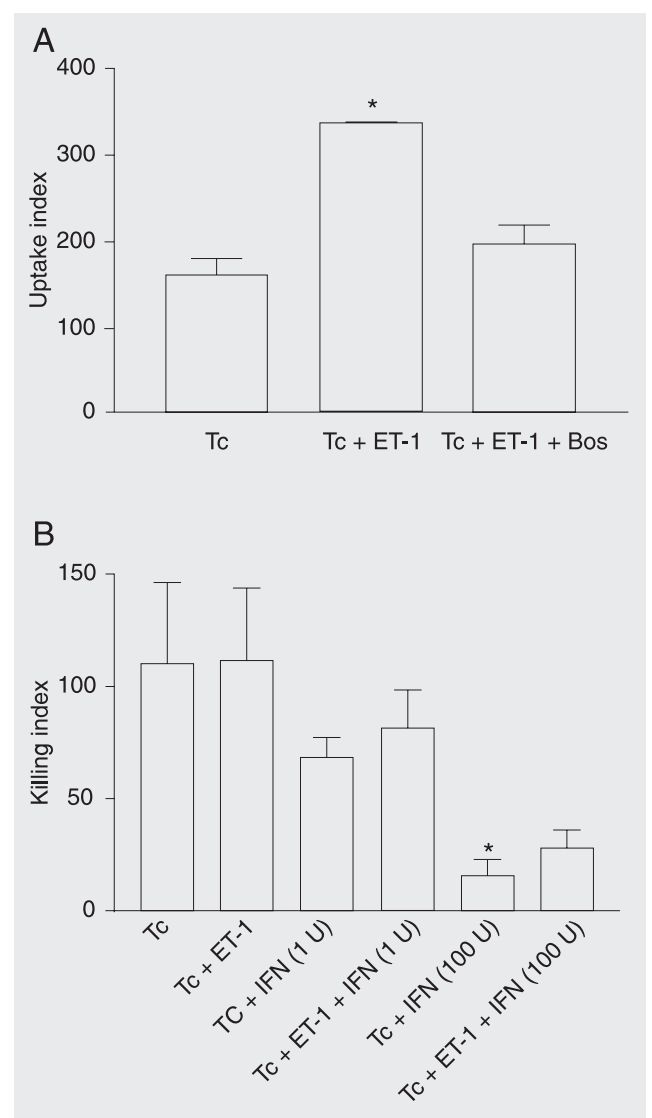

Figure 4. Endothelin-1 enhances the uptake but not the killing of Trypanosoma cruzi (Tc) by macrophages in vitro. Peritoneal macrophages were infected with parasites at a ratio of $1: 2$ and the number of intracellular parasites per 400 macrophages was counted after $2 \mathrm{~h}$ (uptake index, A) or $48 \mathrm{~h}$ (killing index, B). In $A$, macrophages were pre-stimulated in vitro with medium alone (Tc), $0.1 \mu \mathrm{M}$ ET-1 or $1 \mu \mathrm{M}$ ET-1 plus bosentan (Bos). In B, macrophages were pre-stimulated with medium alone (Tc), $0.1 \mu \mathrm{M}$ ET-1, IFN- $\gamma$ (1 or $100 \mathrm{U}$ ) or ET-1 plus IFN- $\gamma$ (1 or $100 \mathrm{U}$ ). Data are reported as the means \pm SEM of triplicates in each group. ${ }^{*} P<0.05$ when comparing ET-1-treated macrophages and medium- or ET-1 plus bosentan-treated macrophages (Student $t$-test). Results were repeated twice. 
Indeed, we have previously shown that activation of macrophages with mediators such as chemokines, leukotriene $\mathrm{B}_{4}$ and plateletactivating factor induces an early uptake of parasites that is followed by a significant enhancement of killing at $48 \mathrm{~h}$ (19-21). Akin to the above-mentioned mediators, ET-1 is an agonist capable of activating 7-transmembrane spanning receptors. Thus, we speculated whether the enhanced number of broken nests could be associated with an effect of ET-1 on parasite uptake and killing. There was an increase in the uptake of parasites but this did not result in enhancement of killing or enhancement of IFN- $\gamma$-induced killing. The levels of NOx were similar in the pres- ence or absence of ET-1 after $48 \mathrm{~h}$ (data not shown), concurring with the lack of effect of ET-1 on parasite killing. Taken together, the in vitro data agree with the parasitemia and lethality findings that suggest that blockade of ET-1 receptors has only a minor role in $T$. cruzi infection in mice.

\section{Acknowledgments}

We are grateful to Valdinéria Borges, Maria Luiza Silva and Carlos Henrique da Silva for technical support. We are also grateful to Actellion (Allschwil, Switzerland) for the kind donation of bosentan.

\section{References}

1. Rocha MO, Ribeiro AL, Teixeira MM. Clinical management of chronic Chagas cardiomyopathy. Front Biosci 2003; 8: e44-e54.

2. Hickey KA, Rubanyi G, Paul RJ, Highsmith RF. Characterization of a coronary vasoconstrictor produced by cultured endothelial cells. Am J Physiol 1985; 248: C550-C556.

3. Gillespie MN, Owasoyo JO, McMurtry IF, O'Brien RF. Sustained coronary vasoconstriction provoked by a peptidergic substance released from endothelial cells in culture. J Pharmacol Exp Ther 1986; 236: 339-343.

4. Yanagisawa M, Kurihara H, Kimura S, Tomobe $\mathrm{Y}$, Kobayashi M, Mitsui $\mathrm{Y}$, et al. A novel potent vasoconstrictor peptide produced by vascular endothelial cells. Nature 1988; 332: 411-415.

5. Luscher TF, Barton M. Endothelins and endothelin receptor antagonists: therapeutic considerations for a novel class of cardiovascular drugs. Circulation 2000; 102: 2434-2440.

6. Salomone OA, Caeiro TF, Madoery RJ, Amuchastegui M, Omelinauk $M$, Juri $D$, et al. High plasma immunoreactive endothelin levels in patients with Chagas' cardiomyopathy. Am J Cardiol 2001; 87: 1217-1220.

7. Wittner M, Christ GJ, Huang H, Weiss LM, Hatcher VB, Morris SA, et al. Trypanosoma cruzi induces endothelin release from endothelial cells. J Infect Dis 1995; 171: 493-497.

8. Huang H, Petkova SB, Pestell RG, Bouzahzah B, Chan J, Magazine $\mathrm{H}$, et al. Trypanosoma cruzi infection (Chagas' disease) of mice causes activation of the mitogen-activated protein kinase cascade and expression of endothelin-1 in the myocardium. $J$ Cardiovasc Pharmacol 2000; 36: S148-S150.

9. Petkova SB, Tanowitz HB, Magazine HI, Factor SM, Chan J, Pestell RG, et al. Myocardial expression of endothelin-1 in murine Trypanosoma cruzi infection. Cardiovasc Pathol 2000; 9: 257-265.

10. Jelicks LA, Chandra M, Shirani J, Shtutin V, Tang B, Christ GJ, et al. Cardioprotective effects of phosphoramidon on myocardial structure and function in murine Chagas' disease. Int $J$ Parasitol 2002; 32: 1497-1506.

11. Morris SA, Weiss LM, Factor S, Bilezikian JP, Tanowitz H, Wittner
M. Verapamil ameliorates clinical, pathologic and biochemical manifestations of experimental chagasic cardiomyopathy in mice. J Am Coll Cardiol 1989; 14: 782-789.

12. Tanowitz HB, Morris SA, Weiss LM, Bilezikian JP, Factor SM, Wittner $M$. Effect of verapamil on the development of chronic experimental Chagas' disease. Am J Trop Med Hyg 1989; 41: 643-649.

13. Chandra M, Shirani J, Shtutin V, Weiss LM, Factor SM, Petkova SB, et al. Cardioprotective effects of verapamil on myocardial structure and function in a murine model of chronic Trypanosoma cruzi infection (Brazil strain): an echocardiographic study. Int J Parasitol 2002; 32: 207-215.

14. Camargos ER, Machado CR, Teixeira AL Jr, Rocha LL, Ferreira AJ, Almeida AP, et al. Role of endothelin during experimental Trypanosoma cruzi infection in rats. Clin Sci 2002; 103 (Suppl 48): 64S-67S.

15. Camargos ER, Rocha LL, Rachid MA, Almeida AP, Ferreira AJ, Teixeira AL Jr, et al. Protective role of ETA endothelin receptors during the acute phase of Trypanosoma cruzi infection in rats. Microbes Infect 2004; 6: 650-656.

16. Brener $Z$. Therapeutic activity and criterion of cure on mice experimentally infected with Trypanosoma cruzi. Rev Inst Med Trop São Paulo 1962; 4: 389-396.

17. Rachid MA, Camargos ER, Barcellos L, Marques CA, Chiari E, Huang $H$, et al. Blockade of endothelin $E T(A) / E T(B)$ receptors favors a role for endothelin during acute Trypanosoma cruzi infection in rats. Microbes Infect 2006; 8: 2113-2119.

18. Opocensky M, Dvorak P, Maly J, Kramer HJ, Backer A, Kopkan L, et al. Chronic endothelin receptor blockade reduces end-organ damage independently of blood pressure effects in salt-loaded heterozygous Ren-2 transgenic rats. Physiol Res 2004; 53: 581-593.

19. Souza DG, Cara DC, Cassali GD, Coutinho SF, Silveira MR, Andrade SP, et al. Effects of the PAF receptor antagonist UK74505 on local and remote reperfusion injuries following ischaemia of the superior mesenteric artery in the rat. Br J Pharmacol 2000; 131: 1800-1808.

20. Aliberti JC, Machado FS, Souto JT, Campanelli AP, Teixeira MM, 
Gazzinelli RT, et al. Beta-chemokines enhance parasite uptake and promote nitric oxide-dependent microbiostatic activity in murine inflammatory macrophages infected with Trypanosoma cruzi. Infect Immun 1999; 67: 4819-4826.

21. Aliberti JC, Machado FS, Gazzinelli RT, Teixeira MM, Silva JS. Platelet-activating factor induces nitric oxide synthesis in Trypanosoma cruzi-infected macrophages and mediates resistance to parasite infection in mice. Infect Immun 1999; 67: 2810-2814.

22. Petkova SB, Huang H, Factor SM, Pestell RG, Bouzahzah B, Jelicks $L A$, et al. The role of endothelin in the pathogenesis of Chagas' disease. Int J Parasitol 2001; 31: 499-511.

23. Tanowitz HB, Huang $H$, Jelicks LA, Chandra M, Loredo ML, Weiss $L M$, et al. Role of endothelin 1 in the pathogenesis of chronic chagasic heart disease. Infect Immun 2005; 73: 2496-2503.

24. Masaki T, Yanagisawa M. Cardiovascular effects of the endothelins. Cardiovasc Drug Rev 1990; 8: 373-385.

25. Parissis JT, Venetsanou KF, Kalantzi MV, Mentzikof DD, Karas SM. Serum profiles of granulocyte-macrophage colony-stimulating factor and $\mathrm{C}-\mathrm{C}$ chemokines in hypertensive patients with or without significant hyperlipidemia. Am J Cardiol 2000; 85: 777-779, A9.

26. Sampaio AL, Rae GA, Henriques MG. Effects of endothelin ETA receptor antagonism on granulocyte and lymphocyte accumulation in LPS-induced inflammation. J Leukoc Biol 2004; 76: 210-216.

27. Ishizawa K, Yoshizumi M, Tsuchiya K, Houchi H, Minakuchi K, Izawa $\mathrm{Y}$, et al. Dual effects of endothelin-1 (1-31): induction of mesangial cell migration and facilitation of monocyte recruitment through monocyte chemoattractant protein-1 production by mesangial cells. Hypertens Res 2004; 27: 433-440.

28. Halim A, Kanayama N, el Maradny E, Maehara K, Terao T. Activated neutrophil by endothelin-1 caused tissue damage in human umbilical cord. Thromb Res 1995; 77: 321-327.

29. Zidovetzki R, Chen P, Chen M, Hofman FM. Endothelin-1-induced interleukin-8 production in human brain-derived endothelial cells is mediated by the protein kinase $C$ and protein tyrosine kinase pathways. Blood 1999; 94: 1291-1299.

30. Coulombe M, Battistini B, Stankova J, Pouliot P, Bissonnette EY. Endothelins regulate mediator production of rat tissue-cultured mucosal mast cells. Up-regulation of Th1 and inhibition of Th2 cytokines. J Leukoc Biol 2002; 71: 829-836.

31. Haller H, Schaberg T, Lindschau C, Lode H, Distler A. Endothelin increases $\left[\mathrm{Ca}^{2+}\right]_{i}$, protein phosphorylation, and $\mathrm{O}_{2}^{-} \cdot$ production in human alveolar macrophages. Am J Physiol 1991; 261: L478-L484. 